\title{
Higher Education in Federal Systems - A Sharing of Experiences
}

\section{JOHN D. DENNISON*}

On May 8, 1991, a colloquium was held in Kingston, Ontario, which focussed upon a topical but somewhat unusual subject - the management of higher education in federated political systems. At the initiative of Gilles Jasmin of the Department of the Secretary of State, and with the encouragement and support of his department and of the Council of Ministers of Education, Canada (CMEC), an organizing committee under the chairmanship of Dr. Ronald Watts, Director of the Institute of Intergovernmental Relations, Queens University, prepared a conference agenda over a two year period. Additional sponsorship was also provided by Queens University and École nationale d'administration publique of the Université du Québec.

Several factors precipitated the planning of the colloquium. Although not explicit in the original discussion, the critical state of Canadian federalism loomed with increasing intensity throughout the pre-conference period. Canada is but one of the many countries in which the constitution delineates the responsibilities of the central (or federal) government, and the federated governments (landers, cantons, states, provinces, etc.).

As described by Pierre Cazalis of the Université du Québec, each federated system has developed a unique structure for the management, organization, planning and financing of education, specifically at the post-high school level. In most constitutions, education and culture are placed under the jurisdiction of the federated states. As Cazalis notes in his introductory theme for the colloquium...

"In federal systems, the interactions between central and provincial governments (or tensions between the forces of centralization and decentralization) take place in a context specific to each country, influenced by geography, history, culture, political structures and legal traditions, which means that higher education operates in a whole variety of environments."

* The University of British Columbia 
Motivated by a number of factors, e.g. high costs of research, particularly in specialized areas, the desire to ensure greater equalization of opportunity throughout the regions, to recognize the role of higher education in a nation's economic development, to contribute to culture and national identity, or to respond to purely political motives, central governments have intruded in various ways into the traditional jurisdiction of the regional governments. In general, authority has generated from the "power of the purse" held by federal governments. In some situations, however, it has been the regional governments which have invited the federal intervention when the costs of maintaining their higher education systems have exceeded their fiscal ability to respond.

Although the constitutional arrangements vary among federated systems, the issues are essentially the same, Do national policies regarding higher education exist? Are such policies to be interpreted as "federal", as distinct from "federalprovincial"? What are the thrust and direction of such national policies? Do national objectives apply to both teaching and research? Do priorities exist within national policies which influence the planning decisions made by institutions of higher education? Are policies in place which direct or determine financial assistance programs which apply to students? What financial arrangements are made regarding the contribution to be made by each level of government? How are the interests of each level of government coordinated in planning and managing the system?

It is conceivable that no specific actions have been taken in particular federated systems to ensure that any of the above issues are addressed. Some may even argue that such is the case in Canada. Albeit, there is every indication that the technological and knowledge-based environment of the twenty-first century will demand economic and educational planning if any advanced society is to survive in a competitive international marketplace.

Questions and issues such as those posed above motivated the planning of the colloquium. In spite of many efforts to bring stability and rational planning to the higher education arena in Canada, few observers express confidence in the future. The latest of a long series of reports (Senate Committee, 1987) further reinforced the view that productive solutions are not apparent. The issue has been further complicated by the political climate which preceded and then followed the Meech Lake Accord. Clearly, the uncertain state of the constitutional future of Canada generates little confidence that helpful answers to the debate about higher education in this country are imminent.

Given the constitutional make-up of Canada, it seemed that, while little may be learned from practices in unitary states, much could be gained by hearing 
about, analyzing and debating such arrangements as are made in comparable federated systems. Accordingly, the organizing committee selected five systems which met the criteria for comparability. These included Australia, Belgium, the United States of America, the Federal Republic of Germany (prior to unification), and Switzerland. Additionally, the committee recognized that another form of federalism was arising as a consequence of the creation of the European Economic Community and input from that source was invited.

\section{The Structure of the Agenda:}

After consideration of the motivation and objectives of the colloquium, a formal agenda was devised which encapsulated four primary themes.

\section{Theme 1: Organization, planning and management of higher education.}

Within this theme a number of specific questions were incorporated. If national objectives do exist, on what criteria and in which ways are they constructed? Within such objectives were both teaching and research considered? What policies and mechanisms are in place to ensure effective management of the higher education system, and what roles are played by each level of government? What provisions exist for the identification of needs and policies for preparation of highly qualified personnel for employment and research? What policies, models and practices are in place for evaluating the outputs of the higher education system and for establishing accountability?

\section{Theme 2: Financing of higher education}

Within this theme the following issues emerged: the methods employed in determining the overall budget assigned to higher education; the nature and design of formulae to allocate funds to member states and/or institutions; policies and mechanisms to better ensure equalization of higher education services among member states; the bases of funding of programs which meet national priorities; the determination of tuition fees and the authority of each level of government in this regard.

\section{Theme 3: Student mobility and recognition of studies and diplomas}

The following aspects of this theme were to be addressed: Policies and procedures relating to programs of student financial assistance and how such 
programs are coordinated between the various levels of government; policies designed to ensure student mobility from region to region and mechanisms to reduce obstacles to mobility; policies and procedures to provide for interprovincial recognition of courses, programs and credentials.

\section{Theme 4: Planning and funding of research}

Within this theme several aspects were to be addressed, i.e.: principles and practices for establishing national policies for research; policies and mechanisms for the provision of financial support for various kinds of research, e.g. national research granting agencies, private sector research, subsidized research by institutions; policies and procedures for financial support of programs for the training of researchers.

\section{Format of the Colloquium:}

In order to obtain first hand and current information on the themes from participating countries, the colloquium was designed to involve relatively brief presentations of information and maximum opportunities for discussion. Consequently, key individuals from the selected countries were requested to prepare background papers which would focus upon the design of the higher education system in each constituency. The papers were constructed under three headings:

Federal structures and current issues in federalism

Higher education, relating particularly to the four themes noted above

Major current issues in higher education, especially as they relate to federalism

The authors of the background papers were as follows:

Canada: David Cameron, Professor of Political Science, Dalhousie University

Australia: Robert H.T. Smith, Vice Chancellor, University of New England and formally Chair, National Board of Employment, Education and Training Germany: Ulrich Teichler, Occupational and Higher Education Research Centre, Kassel Comprehensive University

United States of America: Martin Trow, Professor, Graduate School of Public Policy, University of California, Berkeley 
Belgium: Ignace Hecquet, Director of Institutional Research, Université catholique de Louvain

Switzerland: Augustin Macheret, Professor de droit public et de droit international public, Recteur de l'Université de Fribourg

European Economic Community: Pierre Cazalis, Directeur, du Forum et du Service des conférences de l'École nationale d'administration publique, Université du Québec

In addition to the above, two other background papers were requested. On the first day of the colloquium a session was devoted to the concept of federalism itself, with a paper presented by Ronald Watts of Queens University. Further, a synthesis paper which drew upon common patterns and problems as well as distinctive arrangements as described in the six background papers was prepared by David Cameron.

The organization of the agenda of the colloquium involved relatively brief presentations of higher education systems in the seven federal systems followed by 90 minute discussions of each of the four themes. Finally, the challenging task of summarizing the colloquium was undertaken by Stefan Dupré of the University of Toronto.

\section{The Participants:}

As it was the intention of the organizing committee to ensure a format in which there would be every opportunity for debate and informal exchange of ideas, the number of participants had to be limited. One other planning objective was to ensure that the Canadian representatives constituted no more than one-half of the approximately fifty-five participants. Further, a representative mix of individuals was to be drawn from senior public servants and politicians, business leaders, scholars of federalism and higher education, and administrators in higher education.

Funding for the colloquium came from several sources, primarily the Department of the Secretary of State and the Council of Minister of Education, Canada. Gilles Jasmin and George Molloy represented those two organizations, respectively, on the planning committee.

\section{The Colloquium Proceedings:}

As noted earlier, this colloquium was unique in its focus. The organization and management of higher education in federated systems commands a wide 
literature from many constituencies, but discussions of the specific subject among international scholars and others are rare. The future of federalism in Canada is a matter of sustained debate, although higher education, while an important related issue, is not central to such debate in the wider community. For practitioners, including those with political roles, and for scholars of the subject, systematic study of ways to overcome current inadequacies is long overdue. The colloquium provided a forum for discussion and a considerable body of ideas to energize further attempts at reform. While each federated system represented at the colloquium is organized in a matter consistent with its own historical, economic and socio-cultural traditions, each system can, in turn, learn from each other.

As Cameron notes in his comprehensive synthesis of the seven background papers by referring to points made by Teichler..."First, each federal system is unique, with the result that few, if any, generalizations can be made about federalism and higher education, except that in comparison with unitary systems additional levels of government are involved. Second, federalism extends beyond governments and, consequently, nation-wide coordination is possible through a variety of institutional arrangements besides coordination by a central government. Third, because of the variety of federal arrangements, there is no obvious perspective from which one can judge them in terms of their relative effectiveness."

Any attempt in this report to comment upon the content of the prepared papers, including the summary of the discussions by Professor Dupré, would do little justice to their quality and depth of analysis. It is the intention of the organizing committee to make available the full proceedings of the Colloquium, to be published by Queen's Institute of Intergovernmental Relations with the support of the Department of the Secretary of State.

Scholars and observers of higher education in Canada will learn much, and have a great deal to ponder, from a careful study of these proceedings. In a world in which new political arrangements can occur as rapidly as in Eastern Europe, and at a time in which remarkable international agreements can be accomplished, as in the case of the European Economic Community, Canada's constitutional difficulties assume a new perspective. In the economic realities of the third millennium, the health and effectiveness of Canada's higher education system will be a critical factor. Change is a product of imagination and commitment. There is no reason why this country cannot summon the same will which has characterized the international scene. 